
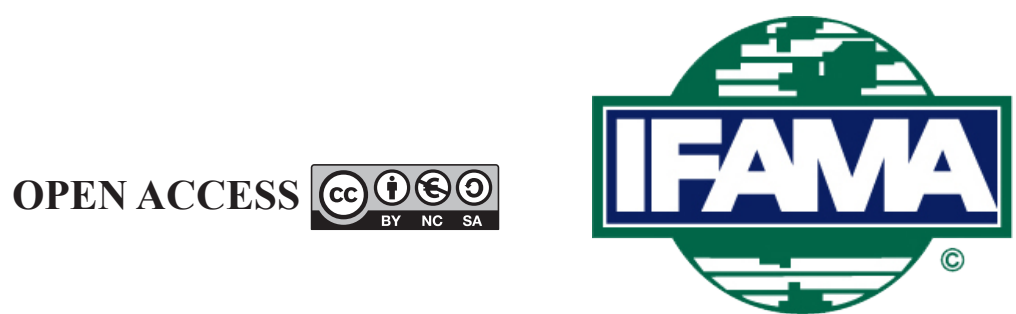

International Food and Agribusiness Management Review

Volume 24, Issue 5, 2021; DOI: 10.22434/IFAMR2020.0182

Received: 20 October 2020 / Accepted: 8 February 2021

\title{
Cal-Maine Foods, Inc.: stock price estimation in the midst of pandemic CASE STUDY
}

\author{
Carlos Omar Trejo-Pech ${ }^{\circledR a}$ and Susan White ${ }^{b}$ \\ ${ }^{a}$ Assistant Professor of Agribusiness Finance, Department of Agricultural and Resource Economics, \\ University of Tennessee, 308-D Morgan Hall, 2621 Morgan Circle, Knoxville, TN 37996, USA \\ ${ }^{b}$ Clinical Professor of Finance, Department of Finance at Robert H. Smith School of Business, \\ University of Maryland, 4455 Van Munching Hall, College Park, MD 20742, USA
}

Both authors contributed equally to this manuscript

\begin{abstract}
This case concerns an analyst's task to value Cal-Maine Foods, Inc., the largest and only publicly traded U.S. egg production firm. The case takes place in 2020, at the time of the Covid-19 pandemic. Historically volatile egg prices were even more volatile in April 2020, with a large spike in prices that led the state of Texas to sue the firm for price gouging. Added to this, Cal-Maine had an unexpectedly bad earnings report a few months earlier, and prior to that, the firm cut its dividend. How should the analyst incorporate these shocks - or should they be included at all? How can the analyst assess the risk of a company that has volatile revenues and costs and a widely varying beta? Which factors is the analysis most sensitive to? Was the market overvaluing Cal-Maine? Or, was there potential for investors to profit from investing in the firm?
\end{abstract}

Keywords: agribusiness finance, investment finance, equity valuation, cage-free eggs, teaching case study JEL code: G11, G23, M21

\footnotetext{
${ }^{\circledR}$ Corresponding author: ctrejope@utk.edu
}

A teaching note has been prepared for this case study. Interested instructors at educational institutions may request the teaching note by contacting the author or IFAMA. 


\section{Introduction}

In mid-2020, a financial analyst (the analyst, hereafter) at a major investment firm was evaluating CalMaine Foods, Inc. (CALM: NASDAQ). It was definitely not a 'calm' market for eggs. Egg prices were very volatile. Egg prices, as with most commodities, varied with supply and demand. However, there were many overall economy and firm specific factors that impacted supply and demand, some of which were beyond the company's control. For example, were eggs an 'in' food; in other words, were eggs considered healthy eating or bad because eggs impacted cholesterol? Did consumers want eggs produced by conventional methods, which some saw as inhumane treatment of the hens, or were consumers willing to pay more for cage-free or free-range egg production? Were there issues that impacted supply, for example, diseases that sickened hens and reduced egg production? These issues were complicated enough to deal with. Now, the analyst had additional factors to add to her analysis of Cal-Maine Foods (Cal-Maine hereafter).

First, the world was in the middle of a pandemic, with the spread of Covid-19, the disease caused by a novel coronavirus, SARS-CoV-2. In July 2020 there was no cure and no vaccine, and no one could accurately predict how long the crisis would last or how damaging it would be. This made already volatile egg prices even more volatile. Second, Cal-Maine had been charged with price gouging by the state of Texas. Forecasting in this industry was challenging to begin with. Current circumstances would make valuation even more difficult.

The analyst thought her best strategy would be to first look at factors that affected revenues and costs in the egg production industry and then examine factors specific to Cal-Maine. Next, she would develop her best guess forecast for Cal-Maine, decide on an appropriate discount rate, and find Cal-Maine's enterprise and equity values. Given all the uncertainties she expected to find, she would prepare a sensitivity analysis which would identify both a range of values for the firm and which factors had the most impact on value. These factors were the ones that she would need to examine most closely.

\section{The egg production industry: supply, demand, and firms}

There were a number of supply and demand factors to consider. On the supply side, how many laying hens are there, how many eggs do they produce, what was the level of hen mortality? During recent years, there was a concern among egg producers that the hen hatch rate was growing, leading to a potential oversupply of eggs. The number of laying hens hit a new record in April 2019, with 341.5 million hens (Egg Industry Center, 2019). The oversupply of eggs in 2019 resulted in decreased prices and decreased revenues for egg producers. Egg producers had been increasing their flock sizes since 2015 when there were heavy losses of hens because of the highly pathogenic avian influenza. From December 2014 to June 2015, the avian influenza killed chickens and reduced the number of laying hens in the U.S. by $15 \%$ or about 50 million birds. ${ }^{1}$

However, an industry outlook by IBISWorld in July 2020 predicted that shell egg industry revenues would be more stable in the mid- and long-term future (Madigan, 2020). IBISWorld projected that shell egg industry revenues would grow $0.8 \%$ in $2020,1.9 \%$ in $2021,0.1 \%$ in $2022,0.9 \%$ in $2023,1.8 \%$ in $2024,0.9 \%$ in 2025 , and $0.9 \%$ in 2026 . This projected egg industry stability drastically contrasted with the recent erratic egg industry financial performance; the latter caused in part by the avian influenza disease that made supply of eggs highly variable. Figure 1 shows annual growth rates of feed prices - the main component of egg farming cost -, egg prices, and egg industry revenue. IBISWorld's expected rise in revenues was due to low increased per capita egg consumption and slightly higher egg prices.

Egg production in the U.S. was highly concentrated both in terms of production location and number of producers. It was estimated that $51 \%$ of total number of laying hens in the nation was concentrated in 5 states (USDA - NASS, 2019) and more than $80 \%$ of all eggs in the U.S. were produced by about hundred large farmers (Gelles, 2016; Wong, 2017). Cal-Maine, with estimated 16.9\% market share (Madigan, 2020),

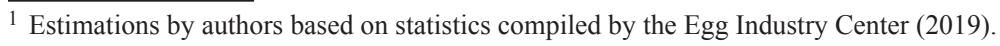




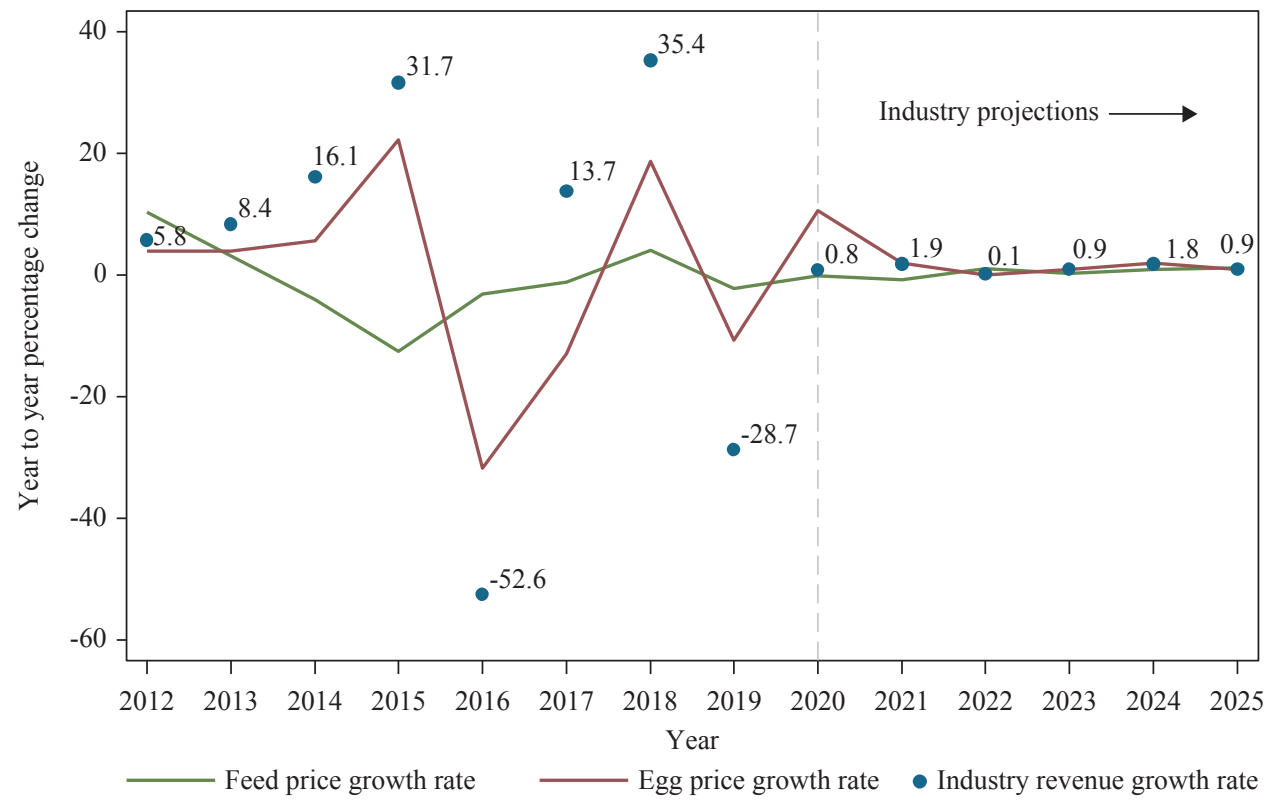

Figure 1. Past and projected year to year change of price of feed, price of eggs and revenue for the U.S. shell egg industry (Madigan, 2020). Labels in the figure show egg industry revenues annual growth.

was the largest and only publicly traded U.S. firm concentrated on egg production and commercialization. ${ }^{2}$ Other players in the egg industry included Rose Acre Farms Inc., Rembrandt Enterprises, Michael Foods Inc., Hillandale Farms Inc., Sparboe Companies, and Opal Foods LLC, which all together captured 18.1\% market share as of 2019 (Trejo-Pech and White, 2020).

Around $80 \%$ of eggs sold in the U.S. were produced with a traditional or conventional production method, in which hens were confined to a small space within cages and egg collection and feeding were largely automated. Those eggs are referred to as non-specialty or conventional eggs. A second category, specialty eggs, included a group of products related to nutritional attributes and/or animal welfare production practices. Specialty eggs included cage-free, certified organic, free range (i.e. from cage-free hens with outdoor access), among others. Cage-free eggs were by far the prevalent specialty sub-category in terms of production volume in the U.S. Cage-free production allowed hens more room to engage in natural behaviors, such as spreading their wings and grooming. ${ }^{3}$ A report by the Industry Egg Center estimated that approximately $20 \%$ of laying hens were grown following cage-free practices, with this share growing rapidly lately (Egg Industry Center, 2019).

The industry had become increasingly regulated to protect hens by moving the industry towards cage-free production practices. Animal welfare groups considered the egg production industry to have the most inhumane conditions of any industry involving animals (Kesmodel, 2015). As early as 2008, California voters passed Proposition 2, which forbad cages that prevented hens from moving freely, lying down or extending their wings, thus requiring California producers to provide additional space per hen in cages and comply with other technicalities. Two years later, California banned egg sales in California from producers in any state that did not meet California regulations. These regulations added costs to egg production, partially passed on by firms to consumers (Mullally and Lusk, 2018). Regulations continued to increase in California, with additional states joining in. In November 2018, the Prevention of Cruelty to Farm Animals Act was approved. The Act required all eggs sold in California to come from cage-free production by 2022. ${ }^{4}$ Michigan, Washington, Ohio, Massachusetts, and Oregon also passed laws regulating laying hen environments.

\footnotetext{
${ }^{2}$ Michael Foods Inc., another large egg producer, was part of the Post Holdings Inc., a diversified publicly traded company.

${ }^{3}$ In a cage-free production system, hens were housed indoors in the facilities under large aviaries rather than in cages. Each hen was provided almost double the space than in cages of a conventional production system. Details on housing facilities are provided by the United Egg Producers (2017) and CSES (2015).

${ }^{4}$ Details on the Prevention of Cruelty to Farm Animals Act can be found in Thomson Reuters (2020).
} 
In the consumer side, large firms including McDonalds, Starbucks, Burger King, Walmart, Kroger, Publix, and many influential restaurants and supermarkets had pledged to buy cage-free eggs only, rather than conventionally produced eggs, by 2025-2026 (Markets Insider, 2017; Wong, 2017). The bottom line for CalMaine was that demand for conventionally produced eggs might decrease, while demand for (and prices of) cage-free produced eggs might increase. However, given financial constraints, it was uncertain how fast egg producers might adjust, if at all, their laying hen housing systems (i.e. their conventional / cage-free products mix) to comply with expected cage-free demand (Trejo-Pech and White, 2020; Wong, 2017).

\section{Cal-Maine Foods}

Eggs - 1.069 billion cartons ${ }^{5}$ of eggs. That's the number of egg cartons Cal-Maine sold in fiscal year 2020, slightly more than in 2019 (U.S. Securities and Exchange Commission, 2020). Cal Maine's 2020 fiscal year (FY) ran from June 2019 to May 2020. FY 2020 marked the seventh consecutive year that the firm sold over a billion carton eggs. Cal-Maine was the largest egg producer in the U.S., and its stock traded under the CALM ticker in NASDAQ. The firm was engaged in all aspects of this business, including producing, grading, packaging, marketing, and distributing shell eggs. Headquartered in Jackson, Mississippi, the firm produced conventional or non-specialty white eggs along with specialty eggs (nutritionally-enhanced, cagefree, organic and brown eggs). The firm also sold egg products such as liquid, frozen, and dried eggs, but at very low levels relative to table eggs sold. Most of Cal-Maine's eggs were sold to club stores, national grocery chains and food service distributors. Its brand names included Egg-Land's Best, Farmhouse, 4-Grain, and Land O' Lakes. To support its egg production, the firm owned breeding facilities, wholesale distribution centers, feed mills, hen housing facilities, pullet growing facilities, and processing and packaging factories. The firm sold its eggs mostly in the southwest, southeast, mid-west, and mid-Atlantic regions of the U.S.

\subsection{Financial information}

Cal-Maine's revenues were slightly lower by 0.7\% in FY 2020 vs FY 2019 (\$1,351.6 million vs $\$ 1,361.2)$. Cal-Maine's billion plus egg production was supported by 9.4 million pullets (young, as yet non-laying chickens) and breeding chickens and 36.2 million laying hens. Table 1 provides selected items of Cal-Maine's financial statements from FY 2016 to FY 2020. Figure 2 shows Cal-Maine stock prices from January 2013 to the end of July 2020. Cal-Maine's stock traded at $\$ 43$ at the end of July 2020, around 20\% up from its average price during March 2020 and 15\% up from its average price during February 2020 (a time when the overall market was decreasing due to the Covid 19 pandemic), and around $20 \%$ down compared to two years before, $\$ 51.55$, by the end of June 2018. In general, Figure 2 shows how Cal-Maine's prices reflected the volatility of input and output prices in the egg industry during the previous years (Figure 1). Figure 3 provides Cal-Maine's earnings per share during the same period, 2013-2020.

\subsection{Prices, production costs, and volumes}

Both prices and production costs in the egg production industry were volatile. Cal-Maine was very integrated, with operations covering producing eggs to getting them to their final destinations. While large egg producers like Cal-Maine were highly automated, production costs included cost of pullets (young chickens), labor, energy, depreciation expenses, and manure and flock cleaning (this occurred when hens were too old to lay regularly and the flock was replaced with new pullets). The largest cost was for feed, a ration typically including corn, soybean meal and other grains. Capital expenditures depended on the type of production, with cage-free facilities requiring a larger initial investment per hen housed than conventional egg production. Capital expenses included land, laying house, and equipment.

In addition to being a large producer, Cal-Maine also did packaging, marketing, and distribution of eggs, alone and with partner firms. The firm's cost of goods sold - depreciation expenses included -, was relatively

\footnotetext{
${ }^{5}$ One carton holds a dozen (12) eggs.
} 
stable around $85 \%$ of total revenues during fiscal years 2019 and 2020, but highly variable from 2016 to 2018 (Table 1). Cost of goods sold for Cal-Maine included farm production cost (i.e. shell eggs sold and produced by Cal-Maine); cost of outside egg purchases (i.e. shell eggs sold, purchased by Cal-Maine from other farmers); cost of grading, packaging, and warehouse; and cost of egg products (i.e. liquid frozen and dried eggs). Table 2 shows Cal-Maine's breakdown of cost of goods sold and egg volumes sold by the firm. It was standard in this industry to examine financial metrics on a per dozen eggs basis.

Table 1. Cal-Maine Food Inc. selected financial statement items (\$ thousands) (S\&P Capital IQ, 2020). ${ }^{1}$

\begin{tabular}{|c|c|c|c|c|c|}
\hline Financial statement items & FY 2016 & FY 2017 & FY 2018 & FY 2019 & FY 2020 \\
\hline Revenue & $1,908,650$ & $1,074,513$ & $1,502,932$ & $1,361,188$ & $1,351,609$ \\
\hline Cost of goods sold ${ }^{2}$ & $1,260,576$ & $1,028,963$ & $1,141,886$ & $1,138,329$ & $1,169,102$ \\
\hline Selling general and administrative expenses & 177,760 & 176,032 & 179,316 & 174,795 & 176,237 \\
\hline Operating income (earnings before interest and taxes) & 470,314 & $(130,482)$ & 181,730 & 48,064 & 6,270 \\
\hline Net income & 316,041 & $(74,300)$ & 125,932 & 54,229 & 18,391 \\
\hline Cash and short-term investments & 389,545 & 156,026 & 331,017 & 319,428 & 232,293 \\
\hline Receivables & 79,278 & 117,200 & 85,839 & 71,760 & 98,375 \\
\hline Inventory & 154,799 & 160,692 & 168,644 & 172,237 & 187,216 \\
\hline Other current assets & 2,661 & 2,288 & 2,020 & 4,328 & 4,367 \\
\hline Total current assets & 626,283 & 436,206 & 587,520 & 567,753 & 522,251 \\
\hline Net property, plant and equipment & 392,274 & 458,184 & 425,384 & 456,294 & 560,584 \\
\hline Long-term investments & 53,975 & 65,731 & 72,506 & 70,954 & 63,731 \\
\hline Other long-term assets & 39,233 & 72,973 & 65,037 & 61,277 & 60,128 \\
\hline Total assets & $1,111,765$ & $1,033,094$ & $1,150,447$ & $1,156,278$ & $1,206,694$ \\
\hline Accounts payable & 36,262 & 30,629 & 37,840 & 39,210 & 55,904 \\
\hline Accrued expenses & 30,869 & 29,224 & 31,923 & 34,001 & 36,278 \\
\hline Current portion of long-term debt & 16,320 & 4,826 & 2,196 & 642 & 0 \\
\hline Other current liabilities & 0 & 0 & 35,879 & 1,054 & 1,001 \\
\hline Total current liabilities & 83,451 & 64,679 & 107,838 & 74,907 & 93,183 \\
\hline Long-term debt & 9,250 & 6,113 & 2,554 & 641 & 0 \\
\hline Other non-current liabilities & 101,703 & 117,809 & 84,373 & 90,924 & 103,836 \\
\hline Total liabilities & 194,404 & 188,601 & 194,765 & 166,472 & 197,019 \\
\hline Total equity & 917,395 & 844,529 & 955,692 & 989,790 & $1,009,675$ \\
\hline Depreciation and amortization & 44,592 & 49,113 & 54,026 & 54,650 & 58,103 \\
\hline Cash from operating activities & 388,463 & $(45,937)$ & 200,358 & 115,083 & 73,609 \\
\hline Capital expenditure & $(76,100)$ & $(66,700)$ & $(19,700)$ & $(68,000)$ & $(124,200)$ \\
\hline Sale of property, plant, and equipment & 2,860 & 84 & 963 & 1,575 & 3,306 \\
\hline Cash acquisitions & 0 & $(85,800)$ & 0 & $(17,900)$ & $(44,700)$ \\
\hline Investment in marketable and equity securities & $(151,300)$ & 198,543 & $(151,700)$ & 28,582 & 104,157 \\
\hline Other investing activities & 5,427 & 6,586 & 6,581 & 7,904 & 37 \\
\hline Cash from investing activities & $(219,113)$ & 52,713 & $(163,856)$ & $(47,839)$ & $(61,400)$ \\
\hline Total debt repaid & $(25,300)$ & $(16,500)$ & $(4,800)$ & $(3,800)$ & $(1,700)$ \\
\hline Repurchase of common stock & $(1,800)$ & $(1,700)$ & $(1,100)$ & $(1000)$ & $(900)$ \\
\hline Total dividends paid & $(120,900)$ & 0 & 0 & $(41,700)$ & \\
\hline Cash from financing activities & $(148,900)$ & $(18,300)$ & $(5,721)$ & $(46,500)$ & $(3,400)$ \\
\hline Net change in cash & 20,450 & $(11,524)$ & 30,781 & 20,744 & 8,809 \\
\hline
\end{tabular}

${ }^{1}$ Number in brackets are negative values; FY = fiscal year.

${ }^{2}$ Cost of goods sold includes depreciation and amortization expenses. 


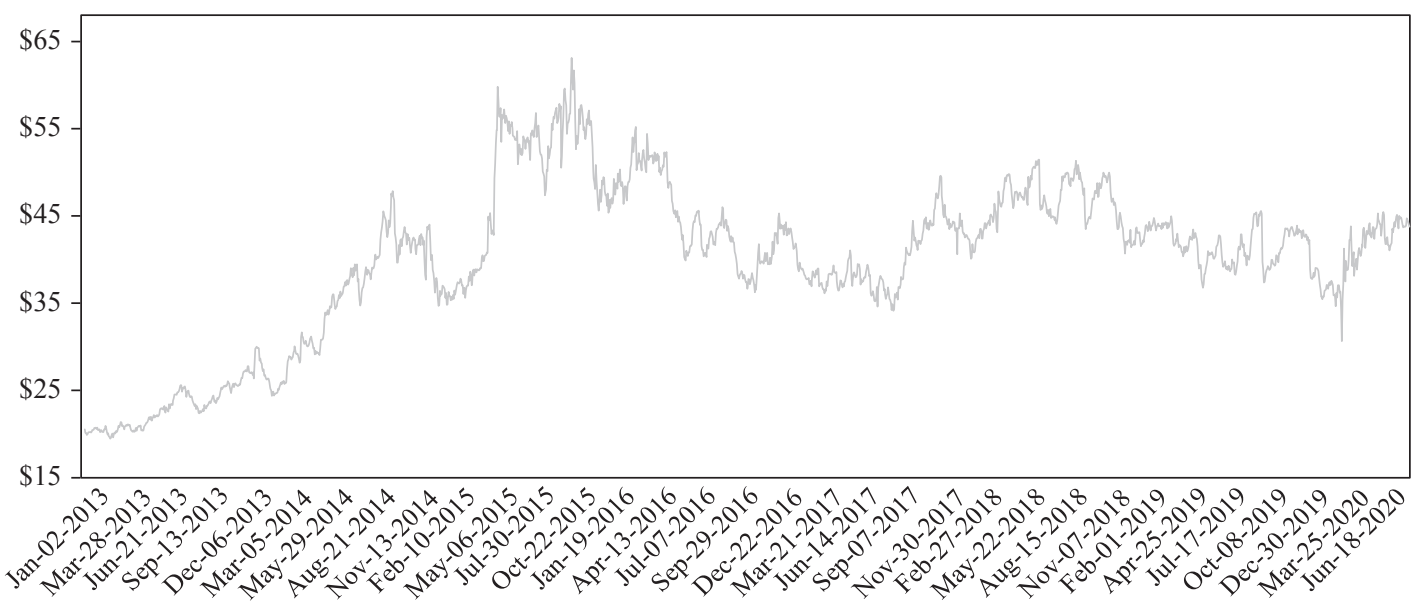

Figure 2. Cal-Maine stock price from January 2013 to July 2020 (S\&P Capital IQ, 2020).

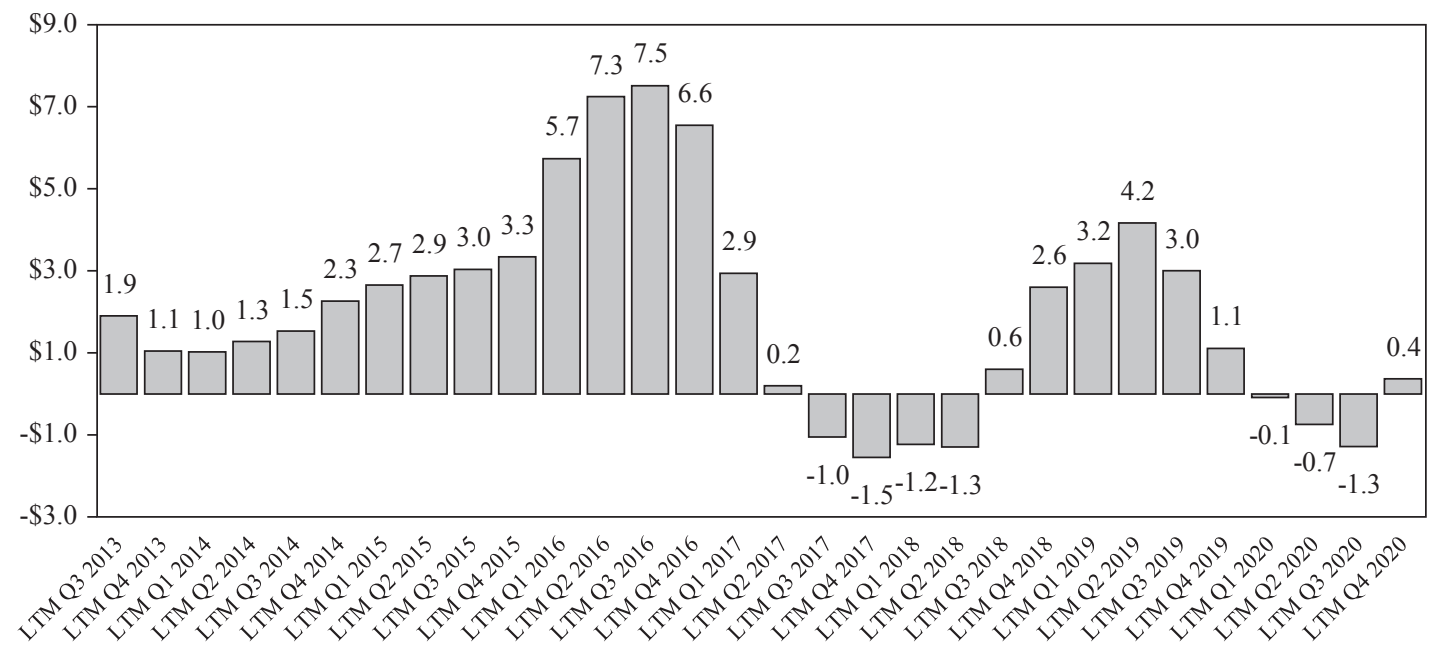

Figure 3. Cal-Maine earnings per share (EPS). LTM stands for last twelve months and Q refers to the quarter EPS were reported to the Securities and Exchange Commission (S\&P Capital IQ, 2020).

With the exception of fiscal year 2016, Cal-Maine produced on average $85 \%$ of the number of eggs it sold, buying the rest from other farmers. As expected, eggs bought outside were more expensive because of transportation costs and sellers' margins. In addition, cost per dozen eggs produced by Cal-Maine were more stable on an annual basis than costs of eggs bought outside. ${ }^{6}$ The higher outside Cal-Maine eggs cost was particularly pronounced during fiscal year 2016 (\$1.98 per dozen compared to $\$ 0.69$ cost of eggs produced by Cal-Maine), when national egg supply was low as the egg industry was recovering from the highly pathogenic avian influenza. But higher outside egg costs also implied higher egg prices in the market. Indeed, unexpectedly 2016 was the best financial year of Cal-Maine in the last five years in terms of revenues and net income.

\footnotetext{
${ }^{6}$ The coefficient of variation (CV) of farm production cost per dozen eggs from 2016 to 2020 was 0.03 compared to 0.14 for outside egg purchases costs during the same period.
} 
Table 2. Breakdown of cost of goods sold (\$ thousands) and volume of eggs sold (dozens) for Cal-Maine. ${ }^{1}$

\begin{tabular}{lrrrrr}
\hline & FY' 2016 & FY 2017 & FY 2018 & FY 2019 & FY 2020 \\
\hline Farm production cost & 562,521 & 598,412 & 603,887 & 635,797 & 677,181 \\
Outside egg purchases and other & 464,008 & 207,495 & 287,472 & 249,605 & 232,027 \\
Processing and packaging & 184,586 & 202,225 & 214,078 & 222,765 & 234,243 \\
Egg products and others & 49,461 & 20,831 & 36,449 & 30,162 & 25,651 \\
Total cost of goods sold & $1,260,576$ & $1,028,963$ & $1,141,886$ & $1,138,329$ & $1,169,102$ \\
Dozen eggs produced & 819,307 & 870,252 & 873,307 & 876,705 & 927,799 \\
Dozen eggs bought outside & 234,290 & 160,878 & 164,406 & 162,195 & 141,351 \\
Dozen eggs sold & $1,053,597$ & $1,031,130$ & $1,037,713$ & $1,038,900$ & $1,069,150$ \\
Farm production (\$/dozen) & 0.69 & 0.69 & 0.69 & 0.73 & 0.73 \\
Outside egg purchases (\$ddozen) & 1.98 & 1.29 & 1.75 & 1.54 & 1.64 \\
\hline
\end{tabular}

${ }^{1}$ Assembled by using annual $10 \mathrm{~K}$ reports by Cal-Maine to the Securities Exchange Commission.

${ }^{2}$ FY = fiscal year. Fiscal year figures reported on May 28, 2016, June 3, 2017, June 2, 2018, June 1, 2019, and May 30, 2020 (U.S. Securities and Exchange Commission, 2020).

Conventionally produced eggs were commodities and therefore highly sensitive to supply and demand. Cage-free eggs cost higher to produce, but could be marketed based on quality of the hens' lives. ${ }^{7}$ Table 3 provides a breakdown of total revenues and net average selling prices per dozen eggs for Cal-Maine during the last five years. As shown in Table 3, the mix of conventional (non-specialty) and specialty eggs sold by Cal-Maine had been stable around $75 \%$ conventional and $25 \%$ non-specialty in terms of volume and had varied in a range between 53\% conventional and 47\% non-specialty and $68 \%$ conventional and $32 \%$ non-specialty in terms of revenues. However, prices have been very volatile, varying from $\$ 1.00$ to $\$ 1.74$ per dozen over the 5 years period. Volatility of both cost of sales and prices made forecasting gross profits (hence, cash flows) for Cal-Maine very challenging for a financial analyst.

Table 3. Revenue breakdown ( $\$$ thousands) and volume of eggs sold (dozens) for Cal-Maine. ${ }^{1}$

\begin{tabular}{|c|c|c|c|c|c|}
\hline & FY'2016 & FY 2017 & FY 2018 & FY 2019 & FY 2020 \\
\hline Non-specialty shell egg revenue & $1,243,377$ & 548,858 & 956,909 & 810,306 & 830,278 \\
\hline Specialty shell egg sales revenue & 584,036 & 490,306 & 493,561 & 504,169 & 485,465 \\
\hline Egg products and other ${ }^{3}$ & 81,237 & 35,349 & 52,462 & 46,713 & 35,866 \\
\hline Total revenues & $1,908,650$ & $1,074,513$ & $1,502,932$ & $1,361,188$ & $1,351,609$ \\
\hline Volume (dozen eggs) & $1,053,597$ & $1,031,130$ & $1,037,713$ & $1,038,900$ & $1,069,150$ \\
\hline Non-specialty shell egg sales (dozen) & 791,058 & 778,538 & 780,362 & 778,052 & 813,255 \\
\hline Specialty shell egg sales (dozen) & 262,539 & 252,592 & 257,351 & 260,848 & 255,895 \\
\hline \multicolumn{6}{|l|}{ Net average selling price } \\
\hline All shell eggs (\$/dozen) & 1.73 & 1.01 & 1.40 & 1.27 & 1.23 \\
\hline Non-specialty eggs (\$/dozen) & 1.57 & 0.70 & 1.23 & 1.04 & 1.02 \\
\hline Specialty shell eggs (\$/dozen) & 2.22 & 1.94 & 1.92 & 1.93 & 1.90 \\
\hline
\end{tabular}

\footnotetext{
7 As discussed in the previous section, cage-free eggs were by far the prevalent egg specialty sub-category in terms of production volume in the U.S. This was also true for Cal-Maine. The terms cage-free and specialty eggs are used interchangeably in this study.
} 
Selling, general and administrative expenses (SG\&A) included marketing, distribution, accounting, and corporate overhead. Breakdown of SG\&A is shown in Table 4. SG\&A represented, on average, 13\% of Cal-Maine's revenues during the 5-year period.

\subsection{Egg production strategy.}

Cal-Maine primarily produced eggs through conventional methods. Hens were confined to a small space and egg collection and feeding were largely automated. Specialty egg production, such as cage-free egg, allows hens more room to engage in natural behaviors, such as spreading their wings, grooming, etc. Cage-free egg production is more costly than conventional production and eggs produced using this method sell for higher prices. In fiscal year 2020, specialty egg sales comprised $24 \%$ of Cal-Maine's total shell egg sales, compared with $25 \%$ the previous year. However, specialty eggs accounted for $37 \%$ of revenues vs $38 \%$ the prior year, in spite of the fact that egg prices had slightly declined during 2020. Regulations had increased the need for more cage-free production. California, for example, had mandated a minimum cage size for eggs produced in that state, along with a rule that all eggs and egg products sold in California needed to come from cage-free production.

In 2019 Cal-Maine announced projects to increase its cage-free egg production in Utah, Texas, and Florida to help meet the additional cage-free production needs, with an expected cage-free capacity of six million hens. Because of the states that had mandated cage-free production and large companies that had promised to sell only cage-free produced eggs, it was important to Cal-Maine and other egg producers to increase their capacity. Most of the 200 producers who made this commitment expected to achieve this goal by 2022-2026 (WATTPoultry.com, 2020). This could be a challenging task. For example, the national sales manager for Lubing Systems, a firm that produces chicken watering and feeding systems and conveyers for eggs, said that Covid-19 would have a big impact on the industry, making it harder for firms that were converting to cage-free production to continue on that path and for new firms to enter the cage-free production business (King, 2020). While Cal-Maine was not converting existing conventional egg production, it had mandated that all new egg production facilities be cage-free.

A few months before this, by October 2018, Cal-Maine announced that the financials of producing cagefree eggs were not working and the firm would cut back on its cage-free production (Duprey, 2017). The analyst thought this was related to the oversupply that developed after the avian flu outbreak that killed about 50 million birds. Flocks were being replenished and with more supply, egg prices were declining from their peak of $\$ 3$ per dozen to about $\$ 1.40$. So, at a time when flocks should be decreasing because of oversupply, Cal-Maine had been increasing its number of hens to provide more cage-free production. The firm decided to cut back unless and until demand and prices increased. The financial analyst in charge of valuing Cal-Maine's stock wondered what assumptions, if any, she could make regarding the potential of additional long-term investments.

Table 4. Selling, general and administrative expenses for Cal-Maine (\$ thousands). ${ }^{1}$

\begin{tabular}{lrrrrr}
\hline & FY $^{\mathbf{2}} \mathbf{2 0 1 6}$ & FY 2017 & FY 2018 & FY 2019 & FY 2020 \\
\hline Specialty egg & 61,294 & 56,522 & 54,300 & 53,263 & 49,237 \\
Delivery expense & 49,629 & 53,282 & 53,177 & 53,595 & 52,230 \\
Payroll and overhead & 39,149 & 35,101 & 37,191 & 38,343 & 44,156 \\
Stock compensation & 3,018 & 3,427 & 3,467 & 3,619 & 3,617 \\
Other expenses & 24,670 & 25,648 & 31,181 & 25,975 & 26,997 \\
Total selling, general and administrative expenses & 177,760 & 173,980 & 179,316 & 174,795 & 176,237 \\
\hline
\end{tabular}

${ }^{1}$ Assembled by authors using annual 10K reports by Cal-Maine to the Securities Exchange Commission.

${ }^{2} \mathrm{FY}=$ fiscal year. Fiscal year figures reported on May 28, 2016, June 3, 2017, June 2, 2018, June 1, 2019, and May 30, 2020 (U.S. Securities and Exchange Commission, 2020). 


\section{Analyst views}

Cal-Maine's financial analyst checked out other analyst views, which varied from mixed to bad by mid-2020. New Constructs recommended that investors avoid Cal-Maine, giving it an 'unattractive' rating, implying the firm had more downside risk than upside potential (New Constructs, 2020). It ranked Cal-Maine as 128 out of 138 consumer non-cyclical sector stocks, stating that the market had overpriced the firm, implying a higher growth rate in revenues (3\%) than New Constructs expected, and noting that Cal-Maine has experienced negative growth in the past.

ValueLine, another equity analysis firm, rated Cal-Maine as a 3 for safety and timeliness (ValueLine, 2020). (Safety referred to total firm risk and timeliness refers whether the stock price was expected to increase or decrease. Values of 3 are average, neither buy nor sell.) ValueLine gave Cal-Maine a grade of B++ for financial strength. It expected an 18-month target price range of $\$ 20-\$ 43$, with a midpoint of $\$ 32$, which was $25 \%$ below the firm's current price. ValueLine projected a 3-to-5-year target price range of $\$ 45-\$ 70$. The price at the time of ValueLine's report was $\$ 41.67$.

Stock Traders Daily recommended buying Cal-Maine at $\$ 39$, with a potential upside price of $\$ 42.91$ (Stock Traders Daily, 2020). CFRA recommended that investors sell Cal-Maine, giving the firm negative ratings on valuation, quality, growth, financial health, and a positive rating for street sentiment; in other words, the market was overvaluing Cal-Maine, and a neutral rating for price momentum (CFRA, 2020). The financial analyst needed to decide for herself. For her preliminary analysis, she had calculated historical financial ratios to build his valuation model (Table 5).

Table 5. Selected financial ratios for Cal-Maine. ${ }^{1,2}$

\begin{tabular}{lccccccc}
\hline & FY 2016 & FY 2017 & FY 2018 & FY 2019 & FY 2020 & Mean & Median \\
\hline Gross margin $^{3}$ & $34.0 \%$ & $4.2 \%$ & $24.0 \%$ & $16.4 \%$ & $13.5 \%$ & $18.4 \%$ & $16.4 \%$ \\
SG\&A margin $^{4}$ & $9.3 \%$ & $16.4 \%$ & $11.9 \%$ & $12.8 \%$ & $13.0 \%$ & $12.7 \%$ & $12.8 \%$ \\
D\&A margin $^{5}$ & $2.3 \%$ & $4.6 \%$ & $3.6 \%$ & $4.0 \%$ & $4.3 \%$ & $3.8 \%$ & $4.0 \%$ \\
EBIT margin $^{6}$ & $24.6 \%$ & $(12.1 \%)$ & $12.1 \%$ & $3.5 \%$ & $0.5 \%$ & $5.7 \%$ & $3.5 \%$ \\
Net income margin $^{\text {NOWC turnover }}$ & $16.6 \%$ & $(6.9 \%)$ & $8.4 \%$ & $4.0 \%$ & $1.4 \%$ & $4.7 \%$ & $4.0 \%$ \\
Net PP\&E turnover $^{8}$ & $11.3 \times$ & $4.9 \times$ & $10.0 \times$ & $7.8 \times$ & $6.9 \times$ & $8.2 \times$ & $7.8 \times$ \\
Noncurrent assets turnover $^{9}$ & $4.9 \times$ & $2.3 \times$ & $3.5 \times$ & $3.0 \times$ & $2.4 \times$ & $3.2 \times$ & $3.0 \times$ \\
CAPEX to D\&A $^{10}$ & $3.9 \times$ & $1.8 \times$ & $2.7 \times$ & $2.3 \times$ & $2.0 \times$ & $2.5 \times$ & $2.3 \times$ \\
Depreciation to net PP\&E $^{11}$ & $1.6 \times$ & $1.4 \times$ & $0.3 \times$ & $1.2 \times$ & $2.1 \times$ & $1.3 \times$ & $1.4 \times$ \\
Total debt to equity $^{12}$ & $2.8 \%$ & $10.7 \%$ & $12.7 \%$ & $12.0 \%$ & $10.4 \%$ & $11.4 \%$ & $11.4 \%$ \\
Altman Z-score & 12.6 & 8.4 & 9.8 & 11.0 & 8.7 & 10.1 & $9.8 \%$ \\
\hline
\end{tabular}

${ }^{1}$ Estimated by authors based on financial data from Table 1, with the exception of the Z-score, estimated by S\&P's Capital IQ (S\&P Capital IQ, 2020).

${ }^{2} \mathrm{FY}=$ fiscal year; number in brackets are negative values.

${ }^{3}$ Gross margin is revenue minus cost of goods sold (including depreciation and amortization) all divided by revenue.

${ }^{4}$ SG\&A margin is selling, general, and administrative expenses divided by revenues.

${ }^{5}$ D\&A margin is depreciation and amortization expenses divided by revenue.

${ }^{6}$ EBIT margin is operating income divided by revenue.

${ }^{7}$ NOWC turnover is net operating working capital (NOWC) turnover, calculated by dividing revenue by NOWC, where NOWC is current assets (except cash plus short-term investments) minus current liabilities (except short-term debt).

${ }^{8}$ Net PP\&E turnover is revenue divided by net (of accumulated depreciation) property, plant, and equipment.

${ }^{9}$ Noncurrent assets turnover is revenue divided by noncurrent assets.

${ }^{10}$ CAPEX to D\&A is capital expenditures (CAPEX) divided by depreciation and amortization (D\&A) expenses.

${ }^{11}$ Depreciation to net PP\&E is depreciation expenses divided by PP\&E net of accumulated depreciation.

12 Total debt to equity is short-term plus long-term debt divided by total equity. 


\section{Cal-Maine and its issues}

The analyst thought that evaluating the equity value of Cal-Maine was difficult enough, considering the volatile prices for eggs and for the costs faced by Cal-Maine, primarily for feed. While it would be difficult, if not impossible to quantify, she needed to consider the impact of two more recent issues: the increased volatility of egg prices because of the coronavirus pandemic and the state of Texas lawsuit against CalMaine. She remembered that Cal-Maine's production facilities were concentrated in the south, in particular in Texas, Alabama and Georgia.

\subsection{Bad earnings and dividend cut in 2020}

Cal-Maine issued its second quarter earnings report in early January 2020. Revenue and earnings per share (EPS) fell sharply (Figure 3) and the stock declined about 10\% (from $\$ 42.45$ on January 3 ) because of the bad news (Figure 2). The total share price decline over the past year was about 13\%. Cal-Maine's second quarter revenue was $\$ 311.5$ million, which was $12.5 \%$ lower than second quarter revenue the previous year. Worse, revenue was $\$ 16.4$ million less than analysts' average expectations. Cal-Maine said this resulted from unfavorable supply and demand, with sales volumes about the same, but average egg prices down $11.5 \%$. Even cage-free eggs did not perform well, with prices down $4.1 \%$ and sales volumes falling by $5.7 \%$. The analyst speculated that lower conventionally produced egg prices cannibalized cage-free egg sales. Cal-Maine said it lost $\$ 0.21$ per share, compared to a profit of $\$ 0.45$ per share in the same quarter of the prior year. This was $\$ 0.30$ below analyst forecasts for earnings. On a twelve months accumulated basis (LTM), losses in the second quarter represented $\$ 0.74$ per share, as shown in Figure 3. LTM EPS further decreased in the third quarter 2020, released at the end of March 2020, and increased in the fourth quarter of 2020, with Cal-Maine producing positive earnings, $\$ 0.40$ per share, for the first time after three quarters of LTM negative results.

The bad news was that Cal-Maine had not paid dividends in 2020. This was consistent with its dividend policy that required cumulative profitability since the previous dividend was paid, ${ }^{8}$ but it was bad news for investors who typically expected dividends. At the time of the earnings announcement, CEO Dolph Baker said, 'In spite of challenging conditions, we will continue to manage our business for the long term, regardless of the volatility in market prices and other external factors outside our control. We are well positioned to execute our growth strategy, and we are committed to making the right investments to support our operations and continue to serve our valued customers' (Green, 2020).

\subsection{A Texas lawsuit}

The financial analyst faced yet another challenge to her valuation: a lawsuit filed April 23, 2020 by the Texas attorney general, Ken Paxton. The lawsuit alleged that Cal-Maine, which was the primary egg supplier in Texas, took advantage of Texas Governor Greg Abbott's disaster declaration because of Covid-19. The lawsuit said egg prices were increased by $300 \%$, even though there were no supply issues or significant production disruptions. Texas considered this to be price gouging, and illegal. The lawsuit announcement quoted Paxton who said, 'No one is exempt from price gouging laws in Texas, including suppliers of grocery stores and pharmacies. My office will not tolerate any person or business taking advantage of hardworking Texans. Those who violate the Texas Deceptive Trade Practices Act will be met with the full force of the law' (Paxton, 2020).

Cal-Maine denied the allegations, stating in a company announcement, 'Cal-Maine has not exploited this tragic national pandemic for gain. Cal-Maine is the largest producer and distributor of fresh shell eggs in the United States and sells the majority of its shell eggs in states across the southwestern, southeastern, midwestern and mid-Atlantic regions. The Company's 3,490+ employees have worked hard during this crisis to meet increased consumer demand. In doing so, Cal-Maine has not changed its longstanding approach to

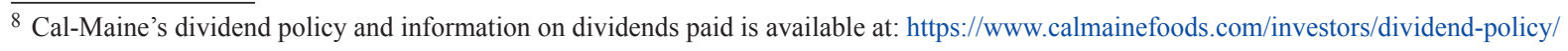


pricing. Any allegation to the contrary is simply not true' (BusinessWire, 2020). The announcement noted the high level of volatility in historical egg prices and stated that the Covid-19 pandemic was very disruptive. Demand for eggs was exceptionally high temporarily and egg prices increased accordingly, and then declined to pre-pandemic levels. Cal-Maine said it used a third-party pricing model that Cal-Maine and its customers mutually agreed to. Cal-Maine pointed out that the firm was a wholesaler and did not set final grocery store retail prices. The analyst remembered that Easter occurred about a week before the lawsuit was filed, and that it was next to impossible to find eggs in her local grocery store. ${ }^{9}$

The analyst took note of the substantial egg price increase at the end of March but was unsure about how, of even if, to include this in her analysis since the filling of the lawsuit did not seem to impact Cal-Maine's stock price (Figure 2). The recent switch from negative to positive EPS (Figure 3), the dividend cut, eggs volume sold by Cal-Maine reaching its maximum over the five years period during fiscal year 2020 (Table 3), the positive industry outlook (Figure 1), and the recent lawsuit were all significant events, but she also needed to look at the overall industry and Cal-Maine's place in that industry. She prepared a SWOT (strengths, weaknesses, opportunities, threats) summarized in Table 6.

\section{Valuing Cal-Maine}

The financial analyst had calculated historical financial ratios for Cal-Maine (Table 5), which she decided would be the best place to start her valuation. As of the 2020 fiscal year report, Cal-Maine had 48.50 million of shares outstanding, zero debt, and relative high cash plus short-term investments ( $\$ 232.3$ million, equivalent to $19 \%$ total assets). The financial analyst planned to project future free cash flows for 2021 to 2026 based on industry outlook's revenue growth rates (Figure 1), and the median values of historical margins and asset efficiency ratios (Table 5). Free cash flows would be discounted by an estimated cost of capital. She had information about Cal-Maine's beta and could use this to calculate a cost of equity (Table 7). ${ }^{10}$ The current 10 -year Treasury bond rate was just under 1\%, extremely low. In her classes she used a market risk premium of $6 \%$ to find the cost of equity. While Cal-Maine did not have any outstanding debt as of the end of 2020, according to the firm's $201910 \mathrm{~K}$ report, its average cost of debt was $5.8 \%$. This rate could be used as a reference for any potential future debt assumed, if any. Further, she researched the long-term GDP growth rate, and found an estimate of $2 \%$ by the Organization for Economic Co-operation and Development, which she thought could be used to calculate a terminal value. A terminal value at the end of year 2026 could be estimated with a perpetuity valuation equation.

She suspected that her discounted cash flow valuation might not even come close to the actual stock price, which had been trading around \$40 in June/July 2020 (Figure 2). Indeed, other analysts had been providing a wide range of estimated prices for Cal-Maine. For example, ValueLine estimated prices ranging from \$20 to $\$ 43$ per share, as discussed above. This is where a thorough sensitivity analysis would be important. What could go wrong - or right - with Cal-Maine? She needed to prepare at least a best and worst case, in addition to her baseline case. Given her preliminary analysis, the financial analyst has realized how highly sensitive the firm's financial performance is to changes in revenues and costs. The analyst compiled data from the last decade and computed Cal-Maine's gross margin, SG\&A margin, and EBIT margin for each year from 2010 to 2020 (Figure 4). It seemed that the highly pathogenic avian influenza, which created uneven supply and demand of eggs, had a major effect on Cal-Maine's financial performance, and that the positives and negatives effects of this outbreak in Cal-Maine's financial performance were mid-term lasting. The analyst thought that a sensitivity analysis of estimated stock price on gross margins might be revealing. The outlook for Cal-Maine was not looking great, but the firm had come through difficult times before. Was the market overvaluing Cal-Maine? Or, was there the potential for investors to profit from the firm?

\footnotetext{
${ }_{9}^{9}$ Average egg prices in the southwest region that included Texas for a dozen large eggs were (BusinessWire, 2020): August 1, 2019 (\$0.64), August 29, 2019 (\$1.29), September 19, $2019(\$ 0.84)$, October 17, $2019(\$ 0.85)$, November 21, $2019(\$ 1.77)$, January 2, $2020(\$ 0.97)$, January 16,2020 (\$0.87), February 27, 2020 (\$1.13), March 26, 2020 (\$3.18), and April 22, 2020 (\$1.16).

${ }^{10}$ In addition to the beta values calculated by the financial analyst, CFRA (2020) estimated Cal-Maine's beta in 1.1.
} 
Table 6. SWOT analysis Cal-Maine Foods. ${ }^{1}$

\section{Strengths}

Production facilities: Cal-Maine had numerous egg productions facilities, using fully-automated, temperature controlled production. The firm owned 6 wholesale distribution centers, 3 breeding facilities, 2 hatcheries, 23 feed mills, 42 egg production facilities, 28 pullet growing facilities, 1 egg products factory and 43 processing and packing facilities. The firm owned 27,458 acres of land.

Customers: Cal-Maine sold to a wide range of club stores, national and regional grocery chains and foodservice distributors. It used electronic ordering and invoicing systems and delivered eggs through its fleet of refrigerated trucks or pick up locations for customers. About $70 \%$ of its sales were to its top 10 customers. The two largest customers, Walmart and Sam's Club provided $33.7 \%$ of Cal-Maine sales.

Liquidity: Cal-Maine had a current ratio of 7.6 in 2019, considerably higher than the agriculture industry average of 3.2. Cash plus short-term investments were $\$ 232.393$ million in 2020 , equivalent to $19 \%$ of the firm's total assets.

\section{Weaknesses}

Revenue decline: As noted in the case, overall Cal-Maine revenues decreased in 2019 compared to 2018 because of decreases in conventionally produced egg prices because of an oversupply that largely resulted from producers increasing flock sizes after losses that occurred during the avian flu epidemic in 2015 . The revenue decline was lower in 2020 relative to $2019(0.7 \%)$.

\section{Opportunities}

Future outlook for egg market: Consumer demand for eggs was growing. Possible reasons included health concerns (desire for egg whites and lower cholesterol omega 3 eggs), popularity of protein diets, higher travel rates. Per capital egg consumption was 279.5 eggs in 2018 and 280.1 in 2019.

Growth through acquisitions: Cal-Maine had announced a growth through acquisition strategy, purchasing Featherland Egg Farms in 2018 and Happy Hen Egg Farms and Foodonics/Dixie Egg in 2017. Consumer spending: In 2019, consumer spending increased due to growing personal income, disposable personal income, and personal consumption expenditures. In January 2020 , personal income increased $0.2 \%$ to $\$ 40.7$ billion; disposable personal income was up $0.2 \%$ to $\$ 30.6$ billion; and consumer expenditures up $0.3 \%$ to $\$ 46.6$ billion, compared to the prior month.

\section{Threats}

High level of competition: Egg producers competed on product quality, price, advertising and promotional activities, brand recognition, convenience, and customer service. Competitors included Del Monte Produce, Hillandale Farms, Bachoco SAV de CV, ISE America, Michael Foods, Moark, Opal Foods, Rembrandt Enterprises, Rose Acre Farms and Sanderson Farms.

Increased regulations: More state and local authorities were regulating egg production including mandating minimum cage sizes per hen, more cage-free egg production, and more regulations concerning the grading, sanitary conditions, labeling and waste disposal. Cal-Maine needed to comply with USDA, EPA and FDA regulations and standards in addition to state and local rules.

Seasonal business: Egg sales were stronger in fall and winter and lower in the summer. Prices began rising in fall, and continued to rise through Thanksgiving, Christmas, and Easter. In the past 10 years, Cal-Maine experienced losses in its fourth quarter, which ended in May, and its first quarter ending in August in three of those years.

${ }^{1}$ Adapted by authors (with fiscal year 2020 numbers) from GlobalData (2020). 
Table 7. Cal-Maine Foods' estimated betas. ${ }^{1}$

\begin{tabular}{lll}
\hline & Weekly & Daily \\
\hline 5-year beta & 0.32 & 0.50 \\
3-year beta & 0.26 & 0.45 \\
1-year beta & 0.12 & 0.44 \\
\hline
\end{tabular}

${ }^{1}$ Estimated by authors regressing Cal-Maine Foods stock returns on S\&P 500 index returns from Yahoo! Finance. Returns are price changes, calculated both on a weekly and daily basis using 1-, 3- and 5-year data.

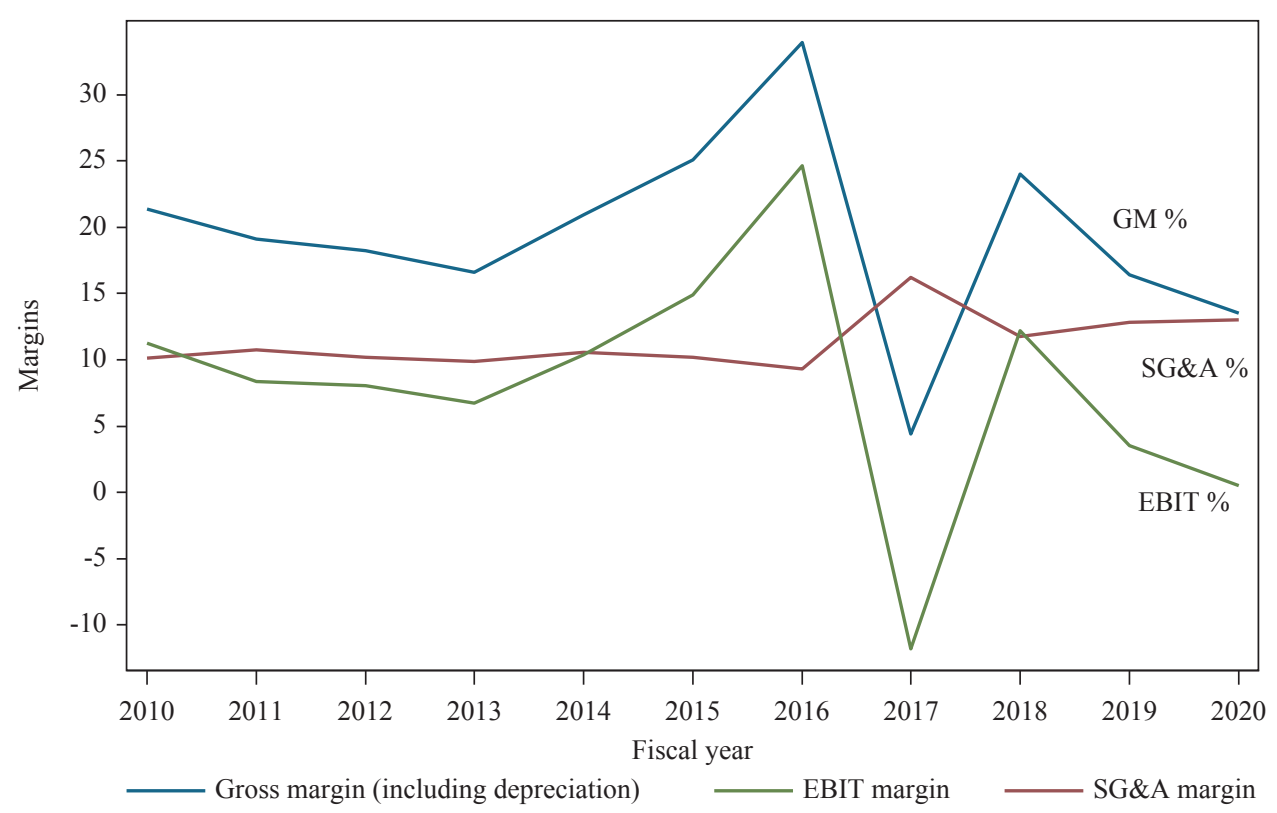

Figure 4. Gross margin, SG\&A margin, and EBIT margin for Cal-Maine (Wharton Research Data Services, 2020). Gross margin = revenue minus cost of goods sold (including depreciation and amortization) all divided by revenue; SG\&A margin = selling, general, and administrative expenses divided by revenues; EBIT margin = operating income divided by revenue.

\section{References}

BusinessWire. 2020. Cal-Maine Foods, Inc. issues response to Texas Attorney General. Business Wire. April 24, 2020. Available at: https://www.businesswire.com/news/home/20200424005552/en/Cal-MaineFoods-Issues-Response-Texas-Attorney-General

Center for Financial Research and Analysis (CFRA). 2020. Cal-Maine Foods, Inc. CFRA quantitative stock report. CFRA, New York, NY, USA.

Coalition for Sustainable Eggs Supply (CSES). 2015. Laying hen housing research project. The Center for Food Integrity, Gladstone, MO, USA. Available at: http://www2.sustainableeggcoalition.org/ final-results

Duprey, R. 2017. Cal-Maine cuts cage-free egg production as interest fades: the public doesn't want to pay the higher costs associated with the more humane care. The Motley Fool. October 18, 2017. Available at: https://www.fool.com/investing/2017/10/18/cal-maine-cuts-cage-free-egg-production-as-interes.aspx

Egg Industry Center. 2019. U.S. flock trends and projections. December 5, 2019. Egg Industry Center, Ames, IA, USA, pp. 1-19.

Gelles, D. 2016. Clearing the cages, but maybe not the conscience: a shift to cage-free eggs may have unintended health effects on hens and their keepers. The New York Times, July 17, 2016. 
GlobalData. 2020. Cal-Maine Foods, Inc.: financial and strategic SWOT analysis review. Available at: https://www.globalmarketanalyst.com/samples/1179128/CalMaine-Foods-Inc-CALM-Financialand-Strategic-SWOT-Analysis-Review

Green, T. 2020. Why shares of Cal-Maine Foods tumbled today. The Motley Fool, January 6, 2020. Available at: https://www.fool.com/investing/2020/01/06/why-shares-of-cal-maine-foods-tumbled-today.aspx

Kesmodel, D. 2015. Flap over eggs: whether to go 'cage-free.' The Wall Street Journal, March 16, 2015. Available at: https://www.wsj.com/articles/latest-flap-on-egg-farms-going-whole-hog-on-cagefree- 1426100062

King, D. 2020. Covid-19 impacts cage-free transition, egg industry. WATTPoultry.com. May 6, 2020. Available at: https://www.wattagnet.com/articles/40252-video-covid-19-impacts-cage-free-transitionegg-industry

Madigan, J. 2020. Chicken egg production in the U.S. cracked up: rising egg consumption is expected be offset by declining egg prices. IBISWorld Industry Report. Available at: http://tinyurl.com/yb5aa6do

Markets Insider. 2017. Cage-free egg pledges yielding to market reality cage-free egg pledges yielding to market reality. Market Insider. Available at: https://markets.businessinsider.com/news/stocks/cagefree-egg-pledges-yielding-to-market-reality-1011562632

Mullally, C. and J.L. Lusk. 2018. The impact of farm animal housing restrictions on egg prices, consumer welfare, and production in California. American Journal of Agricultural Economics 100(3): 649-669. https://doi.org/10.1093/ajae/aax049

New Constructs. 2020. Robo-analyst research, Cal-Maine Foods, Inc. Mergent Online, April 2020. Available at: https://www.newconstructs.com/.

Paxton, K. 2020. AG Paxton files lawsuit to halt price gouging by Cal-Maine Foods, Inc. Ken Paxton Attorney General of Texas, April 23, 2020. Available at: https://www.texasattorneygeneral.gov/news/releases/ ag-paxton-files-lawsuit-halt-price-gouging-cal-maine-foods-inc

S\&P Capital IQ. 2020. Standard \& Poor's NetAdvantage: S\&P Capital IQ Database. S\&P Global Market Intelligence, New York, NY, USA

Stock Traders Daily. 2020. CALM. Stock Traders Daily, La Jolla, CA, USA.

Thompson Reuters. 2020. California Code, Health and Safety Code - HSC § 25991. Available at: https:// codes.findlaw.com/ca/health-and-safety-code/hsc-sect-25991.html

Trejo-Pech, C. and S. White. 2020. Capital budgeting analysis of a vertically integrated egg firm: conventional and cage-free egg production. Applied Economics Teaching Resources 2(4): 34-46.

U.S. Securities and Exchange Commission. 2020. 2020 form 10-K Cal-Maine Foods Inc. U.S. Securities and Exchange Commission, Washington, DC, USA. https://sec.report/Document/0000016160-20000078/\#calm-20200530.htm

United Egg Producers. 2017. Animal husbandry guidelines for U.S. egg-laying flocks. Guidelines for cagefree housing. United Eggg Producers, Johns Creek, GA, USA. https://uepcertified.com/wp-content/ uploads/2019/09/CF-UEP-Guidelines_17-3.pdf

United States Department of Agriculture - National Agricultural Statistics Service (USDA - NASS). 2019. Chicken and eggs (March 2019). Available at: https://downloads.usda.library.cornell.edu/usda-esmis/ files/fb494842n/nk322n184/zk51vq241/ckeg0319.pdf

ValueLine. 2020. The ValueLine research report. Cal-Maine Foods. ValueLine Publishing LLC, New York, NY, USA.

WATTPoultry.com. 2020. Infographics: North American cage-free commitments. News and analysis on the global poultry and animal feed industries. WATTPoultry.com. Available at: https://www.wattagnet. com/articles/40064-infographics-north-american-cage-free-egg-commitments

Wharton Research Data Services. 2020. The global standard for business research. Wharton Research Data Services. Available at: https://wrds-www.wharton.upenn.edu/

Wong, V. 2017. Egg makers are freaked out by the cage-free future. $C N B C$, March 22, 2017. Available at: https://www.cnbc.com/2017/03/22/egg-makers-are-freaked-out-by-the-cage-free-future.html 